DOI https://doi.org/10.18551/rjoas.2017-11.42

\title{
CUSTOMER SATISFACTION IN AN SME: A CUSTOMER PERSPECTIVE IN PERCEIVED VALUE AND LOCAL BRAND IMAGE
}

\author{
Yulianti Farida*, Zamrudi Zakky \\ Management Department, Faculty of Economics, \\ University of Islam Kalimantan Muhammad Arsyad Al Banjari, Indonesia \\ *E-mail: farida.yulianty@yahoo.com
}

\begin{abstract}
This study is aimed to understand the relationship of perceived quality and brand image on customer satisfaction of Sasirangan Consumer. The study were taken at Banjarmasin, South Kalimantan Province, Indonesia. The object of this study is SME's Sasirangan (Kain Sasirangan). The object was taken since it has a deep local wisdom and deep meaning for Banjarmasin society (Banua). The subject taken in this research is youngsters at college. This group of subject taken since today's youngsters has a unique characteristics that also affecting their taste on certain product. The sample was as many as 139 people involved, and executed by using Partial-Least-Square SEM (PLS-SEM). The results of the study shows that either perceived quality or brand image positively increasing the customer satisfaction. Based on the model examination, the perceived value are able to directly affecting the customer satisfaction rather than that affected by brand image. However the indirect effect also indicate that the brand image are also able to mediate the effect of perceived quality on customer satisfaction. The limitation of this study is the object is a single object that may affect the degree of generality against another research.
\end{abstract}

\section{KEY WORDS}

Brand image, perceived quality, customer satisfaction, millennial.

SMEs is growing significantly as a result of an easy trend to start new businesses. Improved market and purchasing power of society makes an SMEs increasingly popular as an alternative to purchase necessity while at the same time attract to start their own SMEs. Indonesian SMEs will face new challenges in the future. The free trade market in the ASEAN Economic Community (AEC) will be a new challenge for Indonesian SMEs. Along with the many types of overwhelming products in the Indonesian market, local SMEs need to compete with imported products. Therefore, innovation is important for SMEs to maintain its market. The role of government to encourage SMEs to be more competitive is also a crucial thing in order to face the free trade market.

Increased competition and consumer expectations encourage SME's to focus on maintaining existing customers. Maintaining an existing market through customer loyalty development is the firm's strategic goal to sustain their business and profits (Tjahyadi, 2006). Understanding the factor influencing customer satisfaction becoming crucial today's especially in this era which mainly dominated by youngster.

When customer thinking about products quality and service quality it will come to several perception such as products quality, since product quality assure product reliability. Focusing on product is basically rely on the finding that states if it has a positive relationship between quality and customer satisfaction which leads to purchase intention (Chaudhuri \& Holbrook, 2001).

Brand itself becoming an antecedent of customer satisfaction (Tu, Wang, \& Chang, 2012). In a local brand, brand image remain a primary consideration against particular products purchasing intention (Johnson \& Bruwer, 2007). The company's brand image is a valuable intangible capital that is difficult to replicate and can help the organization achieve sustainable and superior financial performance (Roberts \& Dowling, 2002). 


\section{LITERATURE REVIEW}

Products are all things than can be offered in the market to get attention, demand, consumption or consumption that can satisfy the needs of consumers. Products consist of quality, features, choice or choice, style, brand name, packaging, size, product line, product item, warranty, service (Kotler, P., Keller, K. L., Brady, 2016). Basically there are five levels of products, namely core benefits, basic products, expected products, additional products and potential products (Kotler \& Keller, 2006). High quality of products, give a brand image value through several ways such as high quality give customers a good reason to buy certain products and differs from another competitors while applying a premium price and great power on customer mind. Good perceived quality is inseparable with good brand positioning in customer mind and proved by its functionality (Babakus, Bienstock, \& Van Scotter, 2004).

To achieve customer satisfaction, an organization should ignore about market reviews and advertising and focusing on providing appropriate production facilities and service infrastructure to provide adequate products and services (Gustafsson, Johnson, \& Roos, 2005). Prior studies has indicates that several aspect affecting the customer satisfaction are perceived quality and brand image (Olsen \& Johnson, 2003; Ranjbarian, Sanayei, Kaboli, \& Hadadian, 2012).

There are two perceived quality based on the products and services namely perceived service quality and perceived products quality (Babakus et al., 2004). Some studies have shown that perceived value have a direct impact on customer satisfaction (Snoj, Pisnik Korda, \& Mumel, 2004; Sweeney, Soutar, \& Johnson, 1999; Tam, 2004; Yoo \& Park, 2007). Newest study stated that perceived quality of social enterprise products has positive effects on perceived value. That is, the higher the perception of quality is, the higher the perceptions of functional, emotional and social value are (Choi \& Kim, 2013). Study conducted in automotive industry also indicates that both perceived service quality and perceived product quality increasing the customer satisfaction (Jahanshahi, Gashti, Mirdamadi, Nawaser, \& Khaksar, 2011).

H1: Perceived Quality increases the Customer Satisfaction.

Perceived quality was defined as consumers' judgment about products' excellence or superiority. Prior study proposed that perceived service quality is determined by the difference between expected services and perceived services (Parasuraman, Zeithaml, \& Berry, 1985). In many research, a brand image can be positively affected by perceived quality (Ranjbarian et al., 2012; Selnes, 1993; Zins, 2001).

H2: Perceived Quality Increase Brand Image on Customer.

Brand image could be defined as depicting process of a brand that is brought to the consumer's mind by the brand association (Kotler, P., Keller, K. L., Brady, 2016; Kotler \& Keller, 2006). Brand image can be also defined as consumer's thoughts and feelings about the brand (Roy \& Banerjee, 2008). Many Prior studies found that there is close relationship from brand image on customer satisfaction (Hussain, Nasser, \& Hussain, 2014; Michaelidou, Siamagka, \& Christodoulides, 2011; Sondoh, Omar, Wahid, Ismail, \& Harun, 2007).

H3: Brand Image Increase Customer Satisfaction.

\section{METHODS OF RESEARCH}

According to the research nature, this research is a quantitative research by using explanatory approach. Quantitative research is may simply defined as the research techniques associated with data gathering, analysis, interpretation and presentation of numerical information (Creswell, 2013). This current research goes beyond a descriptive approach and categorized as explanatory research since it tries to explain causal relationship among variables through some hypotheses testing in an empirical setting (Singarimbun \& Effendi, 2011).

Based on the data collection techniques, this research is a survey research. Survey is used to gather any information from respondent by using questionnaire as the primary data gathering instrument (Singarimbun \& Effendi, 2011). Since the population of customers was 
unknown, this research employ Campbell sample formula drawn as many as 139 sample. The whole sample was measured by using 5 point likert scale.

Data analysis employed in this study was using Partial Least Square based on Structured Equation Modeling (PLS-SEM) to reveal the causal relationship among variables. PLS-SEM is a causal modeling approach aimed at maximizing the explained variance of the dependent latent construct (Hair, Gabriel, \& Patel, 2014). Another finding suggest that PLS is a regression based analysis with fewer data assumption and more accurate coefficient results (Mayfield \& Mayfield, 2012). Compared to Covariance Based SEM (CB-SEM), PLS is robust with fewer identification issues (fewer Goodness of fit criteria). In examining the PLSSEM this research employ PLS software namely SmartPLS v. 2.0 to examine the model.

The object of this research is Sasirangan SME's industries that produce the local motive fabric that also called as "Kain Sasirangan" Sasirangan Fabrics in Banjarmasin, South Kalimantan, Indonesia. The subject of this study is youngsters in Banjarmasin city. Youngsters were chosen since their characteristics that are called as a millennial life style in today's modern living. Do the youngsters still aware on the local products particularly which have a local wisdom identity.

\section{RESULTS AND DISCUSSION}

After the data has been completely collected, the next step is examining descriptive statistics and the structural model. According to descriptive frequencies, the largest grand mean of three variable is respectively started from perceived quality (3.85), customer satisfaction (3.84), and brand image (3.74). From this descriptive explanation this descriptive finding, the customer is relatively have a high perceived quality on Sasirangan SME's product. The customer is also shows a great satisfaction on Sasirangan SME's product. And customer also feels that Sasirangan SME's product have a great image on their mind

According to the model running in PLS-SEM employing SmartPLS V2.0 by using 2 steps. First step is the evaluation of construct reliability and validity assessment. Based on the Table 1 below the Cronbach's alpha has met the cut-off value which from those three variable indicates high reliability above 0.9 (cut-off $>0.7$ ). Validity was examined using both convergent and discriminant validity. Convergent validity was reflected by AVE (Average Variance Extracted) that should be higher than 0.50 , in which all of three variable indicates high validity (Hair, Ringle, \& Sarstedt, 2013). Discriminant validity was examined based on the Fornell-Larcker criterion. The formula was the square root of each construct's AVE which results should be greater than its highest correlation with any other construct (Hair et al., 2014). According to Table 1 below the diagonal elements (Bold) are the square root of AVE and the off diagonal are the latent variable correlations (Roldán \& Sánchez-Franco, 2012).

Table 1 - Reliability and Validity Assessment

\begin{tabular}{cccccccc}
\hline & AVE & Composite Reliability & R Square & Cronbachs Alpha & BI & CS & PQ \\
\hline $\mathrm{BI}$ & 0.855 & 0.959 & 0.490 & 0.943 & 0.925 & & \\
$\mathrm{CS}$ & 0.862 & 0.949 & 0.612 & 0.919 & 0.708 & 0.928 & \\
$\mathrm{PQ}$ & 0.794 & 0.975 & & 0.971 & 0.699 & 0.732 & 0.891 \\
\hline
\end{tabular}

Source: SmartPLS Output.

After all of the Reliability Results has met its cutoff value, the next step is assessing the structural model both directly and indirectly. Based on the Statistics calculation below the results support for hypothesis 1 , hypothesis 2 , and hypothesis 3 since the t-calculated is smaller than t-table.

Based on Table 2 Hypothesis 1 proposed a positive relationship between perceived quality and customer intention and it is supported (7.668>1.96). Hypothesis 2 proposed positive relationship between perceived quality and brand image and it is supported 
(13.596>1.96). Hypothesis 3 proposed positive relationship between brand image and Customer Satisfaction and it is supported (6.679>1.96).

Table 3 shows the indirect effect which is calculated by using sobel formula employing sobel calculator to find out the significance level of construct between perceived quality on customer satisfaction mediated by brand image and it is supported (5.995>1.96). The final Structural model was shown in figure 1 below.

Table 2 - Direct Effect

\begin{tabular}{lccc}
\hline \multirow{2}{*}{ Hypothesis } & \multicolumn{3}{c}{ Direct Effect } \\
\cline { 2 - 4 } & Path & $\mathrm{t}$ & Conclusion \\
\hline H1: Perceived Quality increases the Customer Satisfaction & 0.462 & 7.668 & Supported \\
H2: Perceived Quality Increase Brand Image on Customer & 0.699 & 13.596 & Supported \\
H3: Brand Image Increase Customer Satisfaction & 0.385 & 6.679 & Supported \\
\hline
\end{tabular}

Sources: PLS Output.

Table 3 - Indirect Effect

\begin{tabular}{cccc}
\hline \multirow{2}{*}{ Hypothesis } & \multicolumn{3}{c}{ Indirect Effect } \\
\cline { 2 - 4 } & Path & $\mathrm{t}$ & Conclusion \\
\hline Perceived Quality $\rightarrow$ Brand Image $\rightarrow$ Brand Image & 0.790 & 5.995 & Supported \\
\hline
\end{tabular}

Sources: PLS Output.

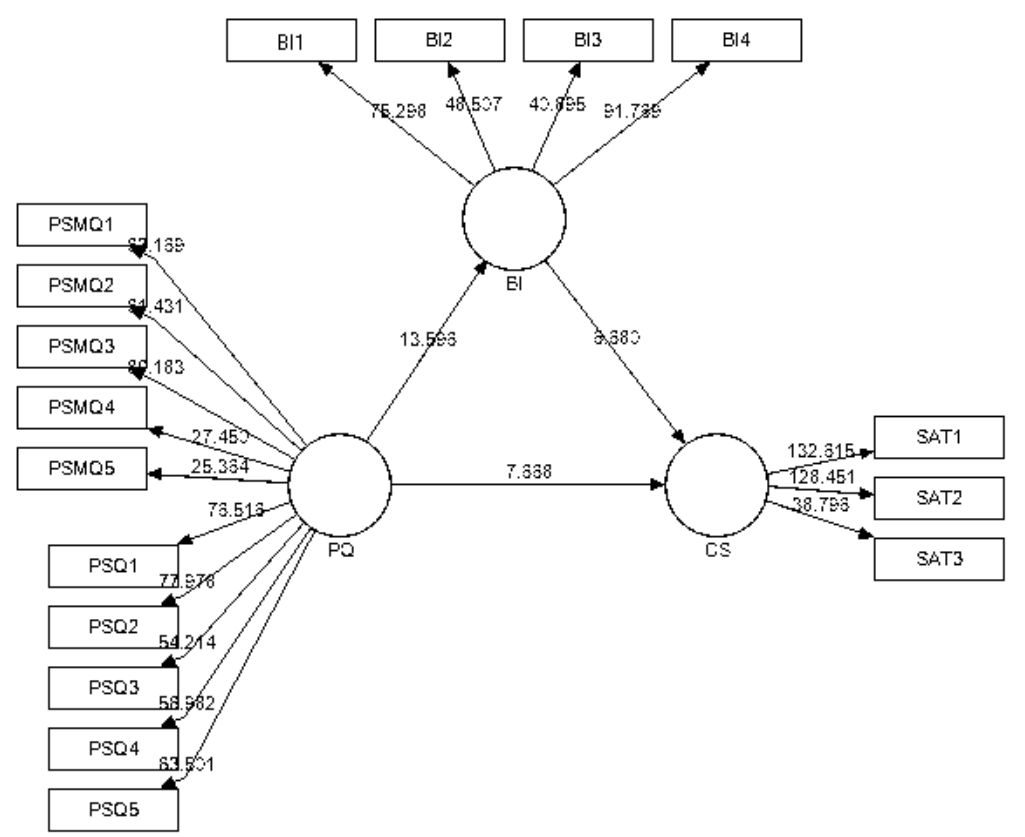

Figure 1 - Structural Model (Sources: PLS Output)

\section{CONCLUSION AND RECOMMENDATION}

This research investigates the effect of perceived value and brand image on customer satisfaction in SME's particularly by the youngster customer. Research model was proposed various prior study that coming with different object. Both of the exogenous variables namely perceived quality and brand image affecting the customer satisfaction in Sasirangan SME's. Between those two exogenous variable, perceived qualities have a dominant effect on customer satisfaction rather than brand image. However the PLS-SEM model examination shows that the indirect effect between perceived quality, brand image and customer satisfaction are greater than direct effect which indicates that by improving either the product 
quality or service quality will increase the brand image on customer mind which leads to customer satisfaction.

Based on the discussion above it is proven that the perceived quality is remain becoming a central consideration rather than the brand image. Which means that the products quality of sasirangan fabric in Banjarmasin city is relatively having a same quality of products and services. This argument is also supported by the grand mean on descriptive statistics above. Most of the customer is satisfied enough with the products from Sasirangan SME's. Though brand image is also have a smaller mean, doesn't mean that brand image become less considerable variable rather than the perceived quality. It can be caused by reversed variable interaction. Prior research also indicates that there is a positive relationship from brand image on perceived quality (Johnson \& Bruwer, 2007; Ranjbarian, Sanayei, Kaboli, \& Hadadian, 2012).

However there is no research without limitation, so does with this study. There are several limitation on this research that can be recommendation for future research. This research is limited on certain industry, so the degree of generality against another research may be limited. Thus the wider the industry and larger amount of respondent with a wider span of respondent characteristic may able the research to generate better conclusion This research is conducted only using a non-recursive model which in another theory it could be designed as a recursive model.

\section{ACKNOWLEDGEMENTS}

This study was conducted based on the cooperation between research team and organized by UNISKA Community Service and Research Buerau (LPPM-UNISKA) and students of faculty of economics. The members of the team are Farida Yulianti as team leader and Zakky Zamrudi as associate researcher. The research team conveying a great gratitude to Director of UNISKA Community Service and Research Bureau, who was supporting this research in their program in 2017.

\section{REFERENCES}

1. Babakus, E., Bienstock, C. C., \& Van Scotter, J. R. (2004). Linking Perceived Quality and Customer Satisfaction to Store Traffic and Revenue Growth*. Decision Sciences, 35(4), 713-737. https://doi.org/10.1111/j.1540-5915.2004.02671.x

2. Chaudhuri, A., \& Holbrook, M. B. (2001). The Chain of Effects from Brand Trust and Brand Affect to Brand Performance: The Role of Brand Loyalty. Journal of Marketing, 65(2), 81-93. https://doi.org/10.1509/jmkg.65.2.81.18255

3. Choi, E. J., \& Kim, S.-H. (2013). The Study of the Impact of Perceived Quality and Value of Social Enterprises on Customer Satisfaction and Re-Purchase Intention. International Journal of Smart Home, 7(1). Retrieved from https://pdfs.semanticscholar.org/92cc/0c0b44de7daf932dc94f6052d66aa14df5f1.pdf

4. Creswell, J. W. (2013). Research Design: Qualitative, Quantitative, and Mixed Methods Approaches. Research design Qualitative quantitative and mixed methods approaches. https://doi.org/10.1007/s13398-014-0173-7.2

5. Gustafsson, A., Johnson, M. D., \& Roos, I. (2005). The Effects of Customer Satisfaction, Relationship Commitment Dimensions, and Triggers on Customer Retention. Journal of Marketing, 69(4), 210-218. https://doi.org/10.1509/jmkg.2005.69.4.210

6. Hair, J. F., Gabriel, M. L. D. da S., \& Patel, V. K. (2014). AMOS Covariance-Based Structural Equation Modeling (CB-SEM): Guidelines on its Application as a Marketing Research Tool. Revista Brasileira de Marketing, 13(2), 44-55. https://doi.org/10.5585/remark.v13i2.2718

7. Hair, J. F., Ringle, C. M., \& Sarstedt, M. (2013). Partial Least Squares Structural Equation Modeling: Rigorous Applications, Better Results and Higher Acceptance. Long Range Planning, 46(1-2), 1-12. https://doi.org/10.1016/j.Irp.2013.01.001

8. Hussain, R., Nasser, A. Al, \& Hussain, Y. K. (2014). Service quality and customer 
satisfaction of a UAE-based airline: An empirical investigation. https://doi.org/10.1016/j.jairtraman.2014.10.001

9. Jahanshahi, A. A., Gashti, M. A. H., Mirdamadi, S. A., Nawaser, K., \& Khaksar, S. M. S. (2011). Study the Effects of Customer Service and Product Quality on Customer Satisfaction and Loyalty. International Journal of Humanities and Social Science , 1(7), 253-260.

Retrieved

from

https://www.researchgate.net/profile/Seyed_Mohammad_Sadegh_Khaksar/publication/23 5791092 Study of the effects of customer_service and product quality_on customer satisfaction_and_loyalty/links/57a096fb08ae-94f454e-b4c9d.pdf

10. Johnson, R., \& Bruwer, J. (2007). Regional brand image and perceived wine quality: the consumer perspective. International Journal of Wine Business Research, 19(4), 276-297. Retrieved

from https://www.researchgate.net/profile/Johan_Bruwer/publication/235278261_Regional_bra nd_image_and_perceived_wine_quality_The_consumer_perspective/links/5440c1f10cf21 $22 \overline{7}$ a11 bb $\overline{6} 74 /$ Regional-brand-image-and-perceived-wine-quality-The-consumerperspective.pdf

11. Kotler, P., Keller, K. L., Brady, M. (2016). Marketing management. Pearson Education Ltd.

12. Kotler, P., \& Keller, K. L. (2006). Marketing Management. Organization (Vol. 22). https://doi.org/10.1080/08911760903022556

13. Mayfield, J., \& Mayfield, M. (2012). The Relationship Between Leader Motivating Language and Self-Efficacy: A Partial Least Squares Model Analysis. Journal of Business Communication, 49(4), 357-376. https://doi.org/10.1177/0021943612456036

14. Michaelidou, N., Siamagka, N. T., \& Christodoulides, G. (2011). Usage, barriers and measurement of social media marketing: An exploratory investigation of small and medium B2B brands. Industrial Marketing Management, 40(7), 1153-1159. https://doi.org/10.1016/j.indmarman.2011.09.009

15. Olsen, L. L., \& Johnson, M. D. (2003). Service Equity, Satisfaction, and Loyalty: From Transaction-Specific to Cumulative Evaluations. Journal of Service Research, 5(3), 184195. https://doi.org/10.1177/1094670502238914

16. Parasuraman, A., Zeithaml, V. A., \& Berry, L. L. (1985). A Conceptual Model of Service Quality and Its Implications for Future Research. Journal of Marketing, 49(4), 41. https://doi.org/10.2307/1251430

17. Ranjbarian, B., Sanayei, A., Kaboli, M. R., \& Hadadian, A. (2012). An Analysis of Brand Image, Perceived Quality, Customer Satisfaction and Re-purchase Intention in Iranian Department Stores. International Journal of Business and Management, 7(6), 40-48. https://doi.org/10.5539/ijbm.v7n6p40

18. Roberts, P. W., \& Dowling, G. R. (2002). Corporate reputation and sustained superior financial performance. Strategic Management Journal, 23(12), 1077-1093. https://doi.org/10.1002/smj.274

19. Roldán, J. L., \& Sánchez-Franco, M. J. (2012). Variance-Based Structural Equation Modeling: Guidelines for Using Partial Least Squares in Information Systems Research. In Research Methodologies, Innovations and Philosophies in Software Systems Engineering and Information Systems (pp. 193-221). https://doi.org/10.4018/978-1-46660179-6.ch010

20. Roy, D., \& Banerjee, S. (2008). CARE-ing strategy for integration of brand identity with brand image. International Journal of Commerce and Management, 17(1/2), 140-148. https://doi.org/10.1108/10569210710776512

21. Selnes, F. (1993). An Examination of the Effect of Product Performance on Brand Reputation, Satisfaction and Loyalty. European Journal of Marketing, 27(9), 19-35. https://doi.org/10.1108/03090569310043179

22. Singarimbun, M., \& Effendi, S. (2011). Metode Penelitian Survei (4th ed.). Jakarta: Pustaka LP3ES.

23. Snoj, B., Pisnik Korda, A., \& Mumel, D. (2004). The relationships among perceived quality, perceived risk and perceived product value. Journal of Product \& Brand 
Management, 13(3), 156-167. https://doi.org/10.1108/10610420410538050

24. Sondoh, S. L., Omar, M. W., Wahid, N. A., Ismail, I., \& Harun, A. (2007). THE EFFECT OF BRAND IMAGE ON OVERALL SATISFACTION AND LOYALTY INTENTION IN THE CONTEXT OF COLOR COSMETIC. Asian Academy of Management Journal, 12(1), 83107. Retrieved from http://web.usm.my/aamj/12.1.2007/AAMJ 12-1-6.pdf

25. Sweeney, J. C., Soutar, G. N., \& Johnson, L. W. (1999). The role of perceived risk in the quality-value relationship : a study in a retail environment. Journal of Retailing, 75(1), 77105. https://doi.org/http://dx.doi.org/10.1016/S0022-4359(99)80005-0

26. Tam, J. L. M. (2004). Customer Satisfaction, Service Quality and Perceived Value: An Integrative Model. Journal of Marketing Management, 20(7-8), 897-917. https://doi.org/10.1362/0267257041838719

27. Tjahyadi, R. A. (2006). Brand Trust Dalam Konteks Loyalitas Merek: Peran Karakteristik Merek, Karakteristik Perusahaan , Dan Karakteristik Hubungan. Jurnal Manajemen, 6(1), 65-78. Retrieved from http://cls.maranatha.edu/khusus/ojs/index.php/jurnalmanajemen/article/view/187

28. Tu, Y.-T., Wang, C.-M., \& Chang, H.-C. (2012). Corporate Brand Image and Customer Satisfaction on Loyalty: An Empirical Study of Starbucks Coffee in Taiwan. Journal of Social and Development Sciences, 3(1), 24-32. Retrieved from https://pdfs.semanticscholar.org/00b4/46b1a605c29326690d8c038c30030b7342cd.pdf

29. Yoo, D. K., \& Park, J. A. (2007). Perceived service quality. The International Journal of Quality \& Reliability Management, 24(9), 908-926. https://doi.org/http://dx.doi.org/10.1108/02656710710826180

30. Zins, A. H. (2001). Relative attitudes and commitment in customer loyalty models. International Journal of Service Industry Management, 12(3), 269-294. https://doi.org/10.1108/EUM0000000005521 